9. Para ele, esta seção II contém o coração de $O$ Capital, isto é, a teoria da mais-valia. 10.Althusser comenta essa afirmação de Marx da seguinte forma: "Dentro de uma concepção hegeliana da ciência (para Hegel há ciência só se esta é filosófica e é por isso que toda verdadeira ciência deve fundar seu próprio começo), Marx pensava, então, que 'em toda ciência, o começo é árduo"” (Althusser 3, p. 27).

11. Conforme afirmara Estrangeiro ao jovem Sócrates no Político (Platão 10), a finalidade de todo diálogo - para além de seus objetivos específicos - é tornar os interlocutores "melhores dialéticos a respeito de qualquer assunto" (284a). Estes aprendizes pressupostos por Marx são, como este mesmo filósofo defendeu, os que querem aprender o novo e a pensar por si mesmos.

12.Vale lembrar que Althusser distingue três situações: o "instinto de classe burguês", o "instinto de classe proletária" e a "posição (objetiva) de classe proletária". Somente esta última, em seu parecer, é plenamente adequada. O Capital auxilia os operários fornecendo-lhes "educação teórica sob a forma de explicações e demonstrações objetivas" (Althusser 3, p. 40).

13. "O próprio Marx [era] filho de burguês liberal (advogado) e Engels da alta burguesia capitalista e, durante vinte anos, ele mesmo [era] capitalista em Manchester. Toda a história intelectual de Marx pode e deve se compreender assim: uma larga, difícil e dolorosa ruptura (...) que [ele] ajudou a definir de maneira decisiva em $O$ Capital" (Althusser 3, p. 40).

14. Vale lembrar a afirmação de Marx: "as análises da substância do valor e da grandeza do valor, procurei torná-las acessíveis ao máximo" (Marx 9, p. 129)

15. O autor aprofunda ainda mais a crítica aos que pretendem facilitar $O$ Capital: "Pensam (...) que podem ser mais didáticos que Marx (...) ou que podem melhorar ou ainda aperfeiçoar o pensamento de Marx alterando a ordem de Marx, recortando seu texto, tirando pedaços, juntando e sobrepondo outros textos (às vezes, esboços do próprio Marx, manuscritos não publicados, etc.). Ora, se esquecem que Marx gastou anos e anos lutando para encontrar a unidade dialética entre forma e conteúdo, ou para usar as palavras do próprio Marx, se esquecem que ele gastou muito tempo para encontrar 'a vida da matéria' (...), a disposição correta das partes, disposição esta que constitui a superação do momento" (Benoit 6, p. 82).

16. Nas palavras de Ítalo Calvino, "os clássicos são aqueles livros dos quais, em geral, se ouve dizer: ‘Estou relendo...' e nunca ‘Estou lendo...”' (Calvino 7, p. 9).

\section{MAQUIAVEL, OU O MAIS LONGO DESVIO: ACONTECIMENTO, ENCONTRO E MATERIALISMO NA FILOSOFIA DO ÚLTIMO ALTHUSSER}

Pablo Azevedo*

Resumo: O presente texto pretende esboçar a leitura de uma teoria do acontecimento no "último Althusser", a partir de dois textos de capital importância no conjunto de sua obra póstuma: Machiavel et nous (1972-1986) e Le courant souterrain du matérialisme de la rencontre (1982). No primeiro texto, Althusser busca através da análise do pensamento do secretário florentino refletir uma teoria da práxis da transformação política; enquanto no segundo ensaio, procura empreender a tarefa de construir genealogicamente uma corrente materialista onde o primado ontológico do encontro substitua a teleologia do materialismo dialético. A partir destes pontos, gostaríamos de buscar uma leitura compositiva dos dois textos, no sentido de percebermos se é possível ler na ontologia althusseriana do materialismo do encontro e em sua interpretação de Maquiavel uma teoria do acontecimento.

Palavras-Chave: Althusser, Acontecimento, Encontro, Maquiavel, Materialismo

Chove. É com esse simples enunciado que Althusser inicia seu texto Le courant souterrain du matérialisme de la rencontre (1982), inicialmente afirmando discorrer sobre a simplicidade de um evento corriqueiro, o ato de chover. Ação impessoal, sem um "sujeito" providencial ou contraprovidencial que execute tal ação (na verdade, isso pouco importa), a chuva emerge na estrutura do texto para além de sua dimensão

* Doutorando em Filosofia UFRJ. 
puramente factual, para tornar-se um princípio ontológico ao redor do qual toda a escritura irá orbitar. Contudo, antes de prosseguirmos com o tema da chuva, nos perguntamos aqui, qual a preocupação que orienta Althusser ao abordar tal questão?

A princípio, a recorrência à chuva nos parece um desvio com relação às preocupações internas ao pensamento althusseriano dos anos 70 , que podemos resumir sinteticamente como uma reversão do hegelianismo interno ao marxismo do século XX, operando fundamentalmente a crítica das categorias de sujeito e fins mistificados pela dialética hegeliana propondo como ferramenta de reversão da dialética um "desvio" via outros operadores materialistas (ALTHUSSER 3, p.67). A partir deste ponto, onde o "desvio" é proposto, Althusser reelabora seu terreno de operação conceitual, sendo que o resultado dessa tarefa nos parece atingir seu clímax em dois textos publicados postumamente: Machiavel et nous (1972-1986) e Le courant souterrain (1982). Apesar do problema da chuva não ser colocado no texto dedicado a Maquiavel, cremos que exista na relação entre estes dois ensaios o espaço para uma reflexão produtiva para pensarmos uma teoria do acontecimento assentada sobre uma ontologia materialista. Antes de propormos esta leitura, voltemos à chuva tal como é abordada no texto Le courant souterrain.

Com relação ao problema da chuva, apesar do tom casual da abertura do ensaio, um feixe complexo de problemas se instaura logo em seus primeiros parágrafos. A recorrência ao tema da chuva é rapidamente interligada a uma reflexão que está posta nos primórdios da filosofia que chamamos de "materialista": a tese epicureana da chuva de átomos. Tese esta reelaborada, alguns séculos depois de Epicuro, por Lucrécio em sua teoria do clinamen (o desvio original que daria origem ao encontro primordial, que faria as séries paralelas da chuva de átomos convergirem produzindo o mundo). O resgate efetuado por Althusser das teses de
Epicuro e Lucrécio visa afirmar o problema da chuva de átomos e do desvio infinitesimal (clinamen) como os princípios constituintes de uma filosofia materialista. Uma ontologia da chuva - um materialismo da chuva - que afirma o desvio originário como constituinte do Encontro que afirma o mundo como um fato consumado, negando, portanto, qualquer causa originária ou teleologia (ALTHUSSER 1, p.542). Na origem, há o vazio de sentido (chuva de átomos), onde o primeiro desvio produz o primeiro encontro, que ao durar, produz uma lógica turbilhonaria e relacional (o fluxo dos encontros) contra qualquer primado do sentido, da causa, da razão e dos fins (ALTHUSSER 1, p.541). Do nada e do vazio de sentido da chuva de átomos o desvio produz um encontro, e a duração deste encontro (o que Althusser chama de "pega"), produz a base ontológica para que o mundo seja uma relação complexa de encontros que duram (ou não), sucedendo-se infinitamente no tempo. É desta base ontológica epicureana/lucreciana que o filósofo francês irá, num primeiro momento, estabelecer genealogicamente o princípio do que ele chama de um materialismo do encontro.

A afirmação do primado do encontro numa ontologia materialista emerge em seu segundo momento, nesta genealogia proposta por Althusser, através da figura de Maquiavel (ALTHUSSER 1, p.543). Para o filósofo, o secretário florentino pensa o materialismo do encontro através da política, ou seja, parte de uma complexa lógica relacional para poder pensar a produção de um "fato" em política - um acontecimento político (ALTHUSSER 1, p.548). Sabemos que Maquiavel não conta com um suporte ontológico em sua obra, e que muito menos há no interior de seu pensamento alguma referência direta a esta ontologia epicureana/lucreciana resgatada no texto de Le courant souterrain. Mas, o que importa para Althusser não é a filiação genética de Maquiavel com relação a Epicuro e Lucrécio, mas a semelhança do topos estrutural-relacional de funcionamento entre o pensamento maquiaveliano e epicureano/lucreciano (ALTHUSSER 1, p.546) ${ }^{2}$. 
Para Althusser, a ontologia relacional dos encontros opera subterraneamente no pensamento político de Maquiavel. Enquanto na superfície do pensamento maquiaveliano só vemos os dados imediatos de uma realidade política (efeitos, acontecimentos políticos), o filósofo marxista percebe nas entranhas das reflexões do secretário florentino um funcionamento profundamente relacional. Assim, a obra de Maquiavel não edificaria em si mesma uma ontologia relacional, mas colocaria um dispositivo de reflexão relacional e aleatório a serviço de um objetivo específico, ou melhor, em função da realização de uma tarefa política: a unidade nacional italiana. Neste sentido, Maquiavel intenta em sua obra estabelecer as condições da produção de um "fato" político que rompe com as condições históricas dadas, compondo em seu pensamento um tecido conjuntural que "agregue" os elementos aleatórios (espalhados na realidade da Itália renascentista) e que permitam constituir o Encontro que produza o estado nacional italiano. Não é apenas constituir este encontro (produzir este fato político, este acontecimento), que preocupa o pensador florentino, mas também conferir alguma durabilidade intrínseca ao mesmo - dito de outra maneira, fazer com que ele "pegue". Althusser nos explicita da seguinte maneira como lê o pensamento político de Maquiavel:

Seu projeto é conhecido: pensar, nas condições impossíveis da Itália do séc. XVI, as condições da constituição de um Estado nacional italiano. Todas as circunstâncias eram favoráveis para imitar a França ou a Espanha, mas não tinham ligação entre si: um povo dividido mas ardente, a fragmentação da Itália em pequenos Estados perimidos e condenados pela história, a revolta generalizada mas desordenada de todo um mundo contra a ocupação e a pilhagem estrangeira, além de uma profunda e latente aspiração popular pela unidade, da qual encontramos testemunho em todas as grandes obras da época (...). Em suma, um país atomizado, do qual cada átomo cai em queda livre sem encontrar seu vizinho. É necessário criar as condições de um desvio e, portanto, de um encontro, para que "pegue" a unidade italiana (ALTHUSSER 1, p.543-44 / 12 - Grifos meus).3

Produzir um desvio que provoque o encontro dos pequenos estados italianos atomizados, que tal como na chuva epicureana, caem em queda livre sem se encontrarem: essa é a tarefa do pensamento maquiaveliano para Althusser. Neste sentido, poderíamos nos arriscar a dizer que a leitura althusseriana incorre em interpretar a obra de Maquiavel como uma tentativa de estruturar um desvio aleatório que produza, através de um encontro de séries de acontecimentos heterogêneos, um novo acontecimento político. Portanto, o aparecimento da filosofia política do pensador florentino em Le courant souterrain nos parece uma tentativa de estruturar, por meio de uma operação reflexiva que passa pela obra de Maquiavel, uma ontologia do acontecimento em política. Desta maneira, Althusser percebe a ontologia relacional emergindo indiretamente no texto maquiaveliano:

É no vazio político que se deve realizar o encontro e que deve "pegar" a unidade nacional. Mas este vazio político é, em princípio, um vazio filosófico. Não se encontra nenhuma Causa que preceda seus efeitos, nenhum Príncipe de moral ou de teologia (como em toda a tradição política aristotélica: os bons e os maus regimes, a decadência dos bons em maus); não se raciocina dentro da Necessidade do fato consumado, mas na contingência do fato a ser consumado. Como no mundo de Epicuro, todos os elementos já estão aí e além, prontos para chover (...), mas eles não existem, são só abstratos, até que a unidade de um mundo os tenha reunido no Encontro que constituirá sua existência (ALTHUSSER 1, p.546 / 14 - Grifos meus). 
As nuvens estão prenhas, o horizonte escurece - mas o que falta para chover? Posto em outros termos, os "elementos afins" que podem concorrer para o Encontro capaz de produzir a unidade nacional italiana estão dispostos no espaço histórico do século XVI, mas por que este acontecimento político não ocorre? É essa angústia que perpassa a reflexão política maquiaveliana: os elementos constituintes do acontecimento político que o pensador florentino almeja construir estão aí, no mundo, espalhados aleatoriamente; contudo, falta algo que os reúna, que promova seu encontro e constitua sua existência. É em busca do lugar onde se opera o desvio (da própria estrutura do desvio), que o pensador florentino procurara incessantemente reunir todas estas séries paralelas de elementos espalhados, pensando o encontro em suas conseqüências materiais mais radicais, no limite do impossível (ALTHUSSER 2, p.62 e 105). Para Althusser tal situação é, em Maquiavel, pensar a conjuntura:

Para que um ser seja (um corpo, um animal, um homem, um Estado ou um Príncipe), é necessário que tenha havido encontro, no pretérito perfeito. Para ficarmos somente em Maquiavel, é necessário que tenha ocorrido encontro (entre affinissables), como, por exemplo, um tal indivíduo e uma tal conjuntura, ou Fortuna $\square$ pois a conjuntura é ela mesma junção, conjunção, encontro fixado, embora movente, que já teve lugar, e que reenvia por sua vez ao infinito suas causas antecedentes, assim como reenvia ao infinito, por outra parte, o resultado [da] série de causas antecedentes, que é um indivíduo determinado (ALTHUSSER 1, p.56566/ 28 - Grifos meus).

A percepção acerca da presença de uma ontologia relacional em Maquiavel nos soa estranha num primeiro momento, e não encontra lugar em nossas velhas cartilhas e resenhas filosóficas de como se deve ler $O$ Príncipe.
O ponto de partida para tal reflexão está elaborado, sobretudo, num ensaio de Althusser publicado postumamente: Machiavel et Nous. Neste ensaio opera-se toda uma reviravolta na perspectiva clássica de como se efetiva a leitura de $O$ Príncipe: desconstrói-se todo a velha "receita de bolo" que lê no opúsculo o princípio de toda a ciência política moderna para, ao invés disto, analisar a obra como um Manifesto Político - estruturalmente semelhante à forma do manifesto paradigmático de Marx e Engels (ALTHUSSER 2, p.54). Não nos cabe aqui discutir a sofisticada elaboração desta perspectiva, mas o que importa é frisar que tal leitura incorre num deslocamento do topos ocupado pelo príncipe (tomado enquanto indivíduo) no interior da obra. A subjetividade do príncipe (sujeito-príncipe) é desconstruída através de uma elegante inversão de pontos de vista, estruturada pela análise de diversos deslocamentos de perspectiva operados no interior da própria obra de Maquiavel (ALTHUSSER 2, p.66-76):

Maquiavel se coloca no ponto de vista do povo, mas, este Príncipe ao qual ele designa a missão de unificar a Itália, deve tornarse um Príncipe popular - ele não é em si mesmo o povo. Da mesma maneira, o povo não é conclamado a tornar-se Príncipe. Há aqui uma dualidade irredutivel entre o lugar do ponto de vista politico e o lugar da força e da prática política; entre o "sujeito" do ponto de vista politico, o povo, e o "sujeito" da prática política, o Príncipe. Esta dualidade, esta irredutibilidade, afeta ao Príncipe e ao povo. Estando o Príncipe definido única e exclusivamente pela função que deverá cumprir, ou seja, pelo vazio histórico que deverá preencher, ele é em si mesmo uma forma de vazio, um puro possivel-impossivel aleatório: nenhum pertencimento de classe irá dispô-lo a empreender sua tarefa histórica, nenhum vínculo social o une ao povo que deverá unificar em nação. Tudo está entregue a sua virtú, ou seja, as condições individuais de seu sucesso. Quanto ao povo, que está à espera deste Príncipe impossível que irá transformá- 
lo em nação - este povo a partir do qual Maquiavel irá definir toda a política do Príncipe - Maquiavel nada lhe exige, nem ao menos lhe sugere que se constitua em povo, que se transforme em povo; nem ao menos o aconselha a tornar-se uma força política. É fato, que veremos Maquiavel distinguir os senhores feudais - aqueles que não trabalham e apenas regozijam-se em oprimir - dos homens do povo que trabalham a terra, a lã ou o ferro, como daqueles que comerciam e especulam. Mas, este povo trabalhador esta começando a se dividir: e nada nos indica que Maquiavel tentou algo para superar esta divisão. A história deve ser feita pelo Príncipe a partir do ponto de vista do povo, mas, o povo ainda não é concebido como o "sujeito" da história (ALTHUSSER 2, p.70. Tradução minha, grifos meus).

Com a desconstrução de que a perspectiva subjetiva do governante é norteadora da prática política buscada em $O$ Príncipe (lugar comum das leituras que compreendem Maquiavel como o fundador da ciência política e como pensador do estado moderno), Althusser compreende o "príncipe" não mais como uma subjetividade que empreende um programa político específico, mas como o lugar de um encontro complexo e como uma força política que produz um "fato" (ALTHUSSER 2, p.55). Tal leitura incorre em desconstruir a perspectiva de que a produção de um acontecimento seja tributária de um Sujeito que orienta a produção da história, para perceber a produção própria da história como uma trama complexa de encontros, cada um dos quais pode "pegar" ou não, pode ser breve ou duradouro, mas sempre sendo provisório (MORFINO 6, p.96). A complexidade de cada encontro não pode ser reduzida a um sujeito operador dado (ou então, às singularidades das partes envolvidas numa relação), mas é tomada como algo que se produz "entre" os termos da relação, sendo que este "entre" próprio de cada relação, é o que constitui a realidade intrínseca à singularidade complexa de cada encontro.
A leitura althusseriana de Maquiavel visa, portanto, perceber a produção política dos fatos fora de uma filosofia da história, deslocando o terreno acontecimental para uma complexidade relacional que não pressupõe como dado o sentido da produção da história. Trata-se, assim, da confrontação direta de um "materialismo aleatório" contra um "materialismo dialético" que, travestido de um idealismo racionalista, recoloca em seu interior todo o problema da necessidade e da teleologia (ALTHUSSER 1, p.539-40) . Tal posição fica clara em Machiavel et nous a partir do investimento teórico por parte de Althusser em ler $O$ Príncipe como um manifesto político. Se ali parece estar presente a inspiração gramsciana de ler o opúsculo maquiaveliano como um manifesto político, se encontra co-presente a tal inspiração uma recusa da teoria do partido como príncipe moderno (MORFINO 6, p.93) ${ }^{4}$.

Gramsci edifica a teoria do partido como príncipe moderno a partir de uma reflexão crítica da leitura de $O$ Príncipe. Tal crítica de Gramsci a Maquiavel incide sobre a utopia interna a $O$ Príncipe de se conclamar um sujeito inexistente e, portanto, incapaz, de dar concretude ao projeto político de unificação da Itália. Dito de outra forma, o fracasso desta obra seria conclamar um sujeito inexistente historicamente para que este expressasse o desejo popular/coletivo de unidade pela criação de um novo estado (o estado nacional popular italiano - o principado novo). Contudo, para Gramsci o partido surge como príncipe moderno ao ser capaz, justamente, de operar aquilo que a utopia maquiaveliana do Príncipe Novo não fora capaz de concretizar:

O moderno príncipe, o mito príncipe não pode ser uma pessoa real, um indivíduo concreto, só pode ser um organismo; um elemento complexo de sociedade no qual já tenha tido início a concretização de uma vontade coletiva reconhecida e afirmada parcialmente na ação. Este organismo já 
está dado pelo desenvolvimento histórico e é o partido político, a primeira célula na qual se sintetizam germes de vontade coletiva que tendem a se tornar universais e totais (GRAMSCI 5, p.16 - Grifos meus).

Quando Althusser lê $O$ Príncipe equiparando-o ao modelo do Manisfesto Comunista de Marx e Engels, o que o filósofo francês objetiva criticar é a idéia de que exista um elemento "dado historicamente" capaz de efetivar a transformação de uma realidade política presente em outra distinta (seja ela a unificação da Itália renascentista, ou a passagem revolucionária do capitalismo ao comunismo): a tese principal é a de que não existe uma necessidade histórica, ou uma razão transcendente, que se concretize como um sujeito que faz a história - seja ele o Príncipe, seja o Partido Comunista. A crítica a um Sujeito (individual ou coletivo) que transforma a história, não é uma apologia a imobilidade política ou uma recusa à possibilidade de se transformar a história; antes disto, é uma afirmação de que apenas uma relação de forças complexa é capaz de transformar a história e de que não existem condições dadas para estruturar esta transformação (ALTHUSSER 2, p.62-63). A questão fundamental é a recusa a qualquer teoria que afirme a prática política a partir de uma filosofia da história, ou seja, que sonhe com a pretensão de que seja possível a partir das compreensões de leis internas à história dar conta da totalidade constitutiva da realidade, e daí, afirmar antecipada e positivamente seu fim último (ALTHUSSER 4, p.285). Esta profunda recusa à teleologia é a um só momento um resgate da dignidade ontológica dos encontros como produtores dos acontecimentos, das relações como constituintes de uma realidade complexa e a negação de qualquer finalidade que orienta a produção acontecimental da história.

Esse combate a teleologia e a idéia de um sujeito da história percorre tanto a ontologia apresentada em Le courant souterrain, como a estrutura de Machiavel et Nous - antes de tudo, é necessário dizer que o pensamento maquiaveliano que surge na Corrente subterrânea é aquele desenvolvido em Machiavel et Nous. Se num primeiro momento podemos ler o texto de Le courant souterrain apenas como uma genealogia que funda um materialismo aleatório, é preciso que nos lembremos que a preocupação do texto não é apenas efetuar uma reflexão puramente ontológica da produção dos encontros ou dos acontecimentos. Não se trata apenas de afirmar a ontologia de um materialismo aleatório, mas de pensarmos, assim como Maquiavel, o materialismo aleatório em política. A recusa de uma filosofia da história (ou seja, de uma leitura teleológica da produção dos acontecimentos) e a afirmação do acontecimento como produto de encontros complexos e aleatórios, antes de ser apenas uma tese filosófica é, também, uma tese política. Sendo assim, é importante que ao pensarmos a produção filosófica do último Althusser, não nos equivoquemos em estabelecer uma ruptura política com relação ao seu pensamento dos anos 70, para afirmarmos puramente uma ontologia do encontro, um materialismo aleatório ou uma filosofia do acontecimento (MORFINO 6, p.81). Sem dúvida, existe, em sua última obra, um deslocamento conceitual e ontológico mas não político. Da mesma maneira que nos anos 70, o Althusser de Machiavel et Nous e de Le courant souterrain du matérialisme de la rencontre é, paradoxalmente, um filósofo comunista que não cessou de desconstruir o comunismo (em sua forma marxiana) como algo imaginário, como triplo mito da Origem, do Sujeito e do Fim" (TOSEL 7, p.39) .

Se tomarmos a ontologia do encontro proposta pelo materialismo aleatório como um primado da relação sobre seus termos, entendemos que as partes envolvidas numa relação só podem ser compreendidas na e pela própria relação, assim como os produtos de tal relação (fatos ou acontecimentos) não podem ser reduzidos aos seus componentes e nem a uma lógica causal e linear de produção (ALTHUSSER 1, p.565-567). 
Contudo, se levarmos em conta a ligação entre a política do primeiro Althusser e esta ontologia proposta em seus últimos escritos, podemos ver que a tese do primado do encontro sobre seus termos está presente na filosofia althusseriana desde os anos 70:

A tese do primado da relação sobre os elementos caracteriza os escritos do primeiro Althusser. Neste sentido, é célebre a posição tomada na Réponse à John Lewis na qual, em oposição a concepção humanista segundo a qual o homem faria a história transcendendo a história precedente, Althusser afirma que 1) apenas as massas fazem a história 2) que a luta de classes é o motor da história. Todavia, as duas teses não estão sobre o mesmo plano, porque a primeira só pode ser entendida corretamente se subordinada à segunda: "Isto significa que o poder revolucionário das massas não é tão potente em função da luta de classes”. Em outras palavras, não é pensável a existência das classes separadamente e anteriormente à luta: "Se deve partir, portanto, da luta de classes para se compreender a natureza e a existência das classes. È preciso colocar a luta de classes em primeiro lugar". E ao longo de poucas linhas conclui: "Primado absoluto da luta de classes" (MORFINO 6, p.82. Minha tradução).

As conseqüências políticas do primado do encontro sobre seus termos dá uma nova tonalidade à luta de classes, que desloca-a da idéia de um sujeito constituinte da história (O Homem), para a concepção de que a luta de classes constitui o processo de produção da história na e pela própria luta, sendo seus produtos (fatos ou acontecimentos) irredutíveis aos termos da relação, sendo entendidos apenas na e pela relação. Tal ontologia, ao descolar o processo de produção da história e da política das amarras de um Sujeito, lança-o no seio dos conflitos de classes e de sua relação imediata de produção dos acontecimentos: assim, assume-se integralmente o presente como vazio para o futuro, afirmando a luta política como o único terreno de uma práxis constitutiva do futuro (ALTHUSSER 2, p.62). É nesses termos que Althusser, ainda nos anos 70, irá propor o marxismo como uma teoria finita em oposição a uma filosofia da história:

Eu creio que a teoria marxista é "finita", limitada: que ela é limitada à análise do modo de produção capitalista, e de sua tendência contraditória, que abre a possibilidade da passagem para a abolição do capitalismo e sua substituição por "outra coisa", que se delineia já “como um vazio" e positivamente, na sociedade capitalista. Dizer que a teoria marxista é "finita" significa sustentar a idéia essencial de que a teoria marxista é totalmente distinta de uma filosofia da história, que pretenda "englobar" todo o devir da humanidade pensando-o efetivamente, e que seria, portanto, capaz de definir, antecipadamente e de modo positivo, o seu fim: o comunismo. A teoria marxista (se se deixa de lado a tentação de uma filosofia da história, à qual o próprio Marx às vezes cedeu, e que dominou de modo esmagador a Segunda Internacional e o período staliniano) está inscrita na fase atual existente, e é limitada a ela: a fase da exploração capitalista. Tudo que ela pode dizer do futuro é o prolongamento alusivo e em negativo da possibilidade objetiva de uma tendência atual, a tendência ao comunismo, que pode ser observada em toda uma série de fenômenos da sociedade capitalista (da socialização da produção às formas sociais “intersticiais”). É preciso observar que é a partir da sociedade atual que pode ser pensada a transição (ditadura do proletariado, sob a condição de não se desvirtuar instrumentalmente esta expressão) e a extinção ulterior do Estado. Tudo o que se diz sobre a transição só pode ser uma indicação induzida por uma tendência atual que, como toda tendência em Marx, é contraposta a outras 
tendências e só pode se realizar por meio de uma luta política. Porém, esta realidade não pode ser prevista já na sua forma positiva determinada: é apenas no curso da luta que as formas positivas podem aparecer à luz do dia, se descobrir, se tornar realidade (ALTHUSSER 4, p. 285286 / 65 - Grifos meus $)^{.5}$

A afirmação de uma lógica relacional e aleatória do acontecimento (subordinada à tese político-filosófica do primeiro Althusser que funda o primado do encontro sobre seus termos: afirmação do primado absoluto da luta de classes) incide, no campo político, em uma recuperação da dignidade da práxis e da experiência humana como produtiva do futuro para além de qualquer teleologia mistificadora. A desconstrução de uma perspectiva teleológica do pensamento marxiano no fim de Le courant souterrain (ALTHUSSER 1, p.569-576), e a tentativa de se estabelecer uma leitura que se alicerce a partir do primado do encontro sobre seus termos, nos parece seguir na mesma direção que já era apontada pelo filósofo marxista desde os anos 70. Em Le marxisme comme théorie “finie”(1978) já vemos a aplicação de toda uma lógica de análise da política, do capitalismo e da luta de classes, perpassada pelos elementos constituintes do pensamento do último Althusser. Ali a recusa do marxismo como uma filosofia da história já se alicerçava numa concepção aleatória dos encontros, preocupada com a produção de um acontecimento a partir da "imediaticidade" das relações, das lutas e alianças, das séries complexas de encontros que produzem a realidade, sendo que "esta realidade não pode ser prevista já na sua forma positiva determinada: é apenas no curso da luta que as formas positivas podem aparecer à luz do dia, se descobrir, se tornar realidade", (ALTHUSSER 4, 286 / 65). Conceber o marxismo como teoria finita, e, portanto, alicerçada na aleatoriedade dos encontros, incorre em deslocar o terreno da práxis de sua subordinação a uma teoria fechada (que enclausura a produção dos acontecimentos numa lógica teleológica, submetida a uma finalidade circunscrita desde sempre na história) para afirmar a práxis como terreno único de produção dos acontecimentos:

Conseqüentemente, a idéia de que a teoria marxista é "finita" exclui totalmente a idéia de que ela seja uma teoria "fechada". Fechada é a filosofia da história, na qual está antecipadamente contido todo o curso da história. Somente uma teoria "finita" pode ser realmente "aberta" às tendências contraditórias que descobre na sociedade capitalista, $\boldsymbol{e}$ aberta ao seu devir aleatório, aberta às imprevisíveis "surpresas" que sempre marcaram a história do movimento operário; aberta, portanto atenta, capaz de levar a sério e assumir em tempo a incorrigível imaginação da história (ALTHUSSER 4, p.286 / 65 - Grifos meus).

A recusa a um Marx teleológico é proposta a partir de uma função teórica fundamental, que é exercida pelo lugar que Maquiavel ocupa na genealogia do materialismo aleatório: o de pensador do materialismo do encontro pela política. As reflexões do secretário florentino põem a ontologia relacional do encontro a serviço de um objetivo político específico - a construção de um desvio potente, capaz de agregar elementos dispersos no presente para concretizá-los num acontecimento político inovador. Contudo, a produção deste acontecimento não está subordinada a um funcionamento teleológico da história, que produz as condições dadas e objetivas para a sua concreção; antes disso, parte-se da ausência (do vazio) de qualquer sentido que produza o encontro entre as tendências dispersas (cada qual com sua história, cada qual independente uma da outra no que se refere ao complexo de relações que a constitui) para se pensar a força política capaz de agregar estas tendências. Neste sentido, longe de ser um utópico, Maquiavel é um pensador do 
acontecimento sob a aleatoriedade que lhe é própria, pensando que a instauração de um acontecimento que "rompa" com a forma política atual só pode ser efetivado a partir de uma nova práxis e de uma nova forma de organização das forças políticas, que só pode dar-se a partir de uma conjuntura material específica (ALTHUSSER 2 , 134-160).

Se a ontologia apresentada em Le courant souterrain preocupase em estabelecer genealogicamente uma ontologia do materialismo aleatório, vemos que esta preocupação ganha um matiz político com a entrada de Maquiavel como filósofo do materialismo do encontro. A inspiração que empurra Allthusser em direção a uma ontologia do encontro é a necessidade de fugir aos modelos teleológicos de produção de um fato (acontecimento): negar uma filosofia da história e afirmar o marxismo como uma teoria finita é, no que se refere à política, recusar as "receitas de bolo" que o marxismo, em suas concepções mais dogmáticas e ortodoxas, extrai de um determinado feixe de leituras teóricas para nortear sua prática política (ALTHUSSER 4, 288-92). Retirando a "ordem" dos fatos de uma leitura teleológica, Althusser objetiva produzir uma perspectiva não teleológica da prática política: centrada na práxis sobre a conjuntura (luta de classes), na tentativa de produzir um desvio (que não está dado pelos elementos aleatórios e descasados em séries heterogêneas); ou seja, uma nova força e prática política capazes de gerar um novo fato, de produzir "pega", de efetivar um encontro durável - enfim, de produzir uma diferença acontecimental em política (desvio), uma transformação que supere as lógicas sedimentadas pelas disjunções seriais reproduzidas no seio do mundo contemporâneo. Desta maneira, a proposta da leitura de uma teoria do acontecimento na filosofia althusseriana não nos parece um "delírio filosófico" se levarmos em conta as seguintes questões:

1) A relação entre as questões políticas do Althusser dos anos 70 e de sua obra póstuma nos possibilita estabelecer uma ligação entre a afirmação do primado do encontro sobre seus elementos (presente em Le courant souterrain e Machiavel et Nous) no que diz respeito a afirmação do primado da luta de classes.

2) Perceber que na afirmação do primado absoluto da luta de classes repousa uma profunda crítica a teleologia como produtora dos fatos (acontecimentos) e norteadora das práticas (práxis) que orientam as lutas políticas. A crítica à teleologia e a uma filosofia da história - elementos que tornam a teoria marxista "fechada" -, incorrem na tentativa de transformar a teoria marxista numa teoria aberta, ou seja, capaz de radicalizar a concepção da práxis transformadora da luta de classes como espaço "absolutamente presente" onde se produzem os acontecimentos (vazio para o futuro).

3) O elogio a Maquiavel como pensador do materialismo aleatório através da política coloca a questão fundamental de se entender o materialismo do encontro para além de uma especulação conceitualabstrata acerca dos acontecimentos; antes, põe a prática da política no centro das preocupações ontológicas althusserianas. Contudo, cremos que só é possível compreender a função teórica de Maquiavel (em sua máxima intensidade) na ontologia althusseriana (tal como proposta em Le courant souterrain) nos apropriando da interpretação proposta pelo filósofo marxista em Machiavel et Nous.

Resta-nos, ainda, um último ponto que contribui para justificar o caminho de se buscar em Althusser uma teoria do acontecimento. A negação de uma leitura teleológica de Marx no seio da filosofia althusseriana se conduz, como já colocamos antes, por uma questão política. Essa discussão política orbita ao redor de um acontecimento que norteia toda a construção da práxis política marxista: o comunismo. Ligar as preocupações políticas de Althusser nos anos 70 às de sua produção filosófica dos anos 80 incorre em não podermos nos desviar desta questão. Contudo, pela forma como apresentamos o materialismo aleatório ao 
longo deste texto, cremos que nosso leitor não confundirá o problema que Althusser se coloca ao pensar a "produção do comunismo", com as fórmulas clássicas pelas quais o marxismo apresentou esta questão política. A crítica althusseriana a um pensamento teleológico que orienta a práxis política e a produção da história, incide, fundamentalmente, sobre a crítica de uma imagem estereotipada do comunismo, ou da utopia do comunismo como o fim da história - pensando, por outro lado, aquilo que poderíamos chamar de "comunismo", como a análise (no seio da realidade capitalista) de uma "tendência contraditória, que abre a possibilidade da passagem para a abolição do capitalismo e sua substituição por "outra coisa", que se delineia já "como um vazio" e positivamente na sociedade capitalista" (ALTHUSSER 4, p.285). Neste sentido, cremos que o problema do "comunismo" compreendido enquanto "acontecimento", estruturado pela perspectiva ontológica do materialismo aleatório, é um ponto importante para permitir-nos ligar a produção teórica do filósofo marxista dos anos 80 às preocupações políticas internas a sua primeira obra:

Pode parecer gratuito nos deixarmos levar por esses jogos teóricos. No entanto, a experiência demonstra que a representação do comunismo que os homens - e especialmente os comunistas - fazem, por mais vaga que seja, não é estranha ao seu modo de conceber a sociedade atual e as suas lutas imediatas e futuras. A imagem do comunismo não é inocente: ela pode nutrir ilusões messiânicas que garantiriam as formas e o futuro das ações presentes, desviá-las do materialismo prático da “análise concreta da situação concreta", alimentar a idéia vazia de "universalidade" — que se encontra em algumas expressões equívocas similares, como o "momento geral”, no qual uma certa "comunidade" de interesses gerais será satisfeita, como se fora a antecipação daquela que poderá ser um dia a universalidade do "pacto social" em uma "sociedade regulada". Esta imagem alimenta, enfim, a vida (ou a sobrevivência) de conceitos dúbios (...). Para decifrar o enigma é necessário retornar à imagem que Marx fazia do comunismo e submeter esta imagem problemática a uma crítica materialista. É através desta crítica que se pode perceber o que ainda resta em Marx de uma inspiração idealista do Sentido da história. Teórica e politicamente, vale a pena fazê-lo (ALTHUSSER 4, 292 / 72 - Grifos meus).

Compreendemos, assim, que a necessidade de se efetivaruma crítica materialista da "imagem" do comunismo feita pelos seguidores de Marx possa alicerçar o ponto comum da elaboração da ontologia do materialismo aleatório composta, simultaneamente, em Le courant souterrain e Machiavel et Nous. Se na ontologia da corrente subterrânea o filósofo marxista se propõe a desconstruir a perspectiva dialética e mistificadora do materialismo histórico (ALTHUSSER 1, p.540), sua última interpretação do pensamento do secretário florentino edifica o mesmo "como o maior filósofo materialista da história" (ALTHUSSER 2, p.161). A imagem de Maquiavel, como filósofo materialista e pensador do materialismo aleatório em política, nos explicita a importância que as reflexões acerca da obra do pensador florentino possuem no interior das reflexões do último Althusser. Na década de 70, o filosofo marxista propunha a necessidade de um desvio na leitura de Marx através de Spinoza para que pudéssemos eliminar o hegelianismo (a dialética e sua teleologia) do marxismo (ALTHUSSER 3, p.67). Contudo, no que se refere à história da filosofia, o desvio efetivado por esta operação crítica ocorreu de maneira ainda mais longa do que havia sido proposta: um desvio através de Maquiavel. Em Althusser, Maquiavel não é apenas o pensador do desvio aleatório em política, mas é também por meio das reflexões do secretário florentino que é efetivado o mais longo 
desvio teórico - desvio através do qual é realizada a crítica materialista ao materialismo dialético.

Chove. Ainda hoje, como nos tempos de Maquiavel, as nuvens estão pesadas e escuras, e não sabemos como ou o que falta para chover. Os "elementos afins", "as tendências virtuais", que podem concorrer para o Encontro capaz de produzir a superação do capitalismo "por outra coisa" estão dispostos na realidade, mas por que este acontecimento político não ocorre? Talvez seja isso que faz com que Maquiavel ainda nos soe estranhamente familiar e seu pensamento nos pareça insólito (ALTHUSSER 4,p.314): assim como o pensador florentino, precisamos pensar as condições políticas de um desvio produtor de um novo acontecimento. Enquanto não há uma nova práxis sobre a conjuntura, chove.

\section{REFERÊNCIAS BIBLIOGRÁFICAS}

1.ALTHUSSER, Louis. Le courant souterrain du matérialisme de la rencontre. In: Écrits philosophiques et politiques. Tome I. Paris: STOCK/ IMEC, 1994. / A corrente subterrânea do materialismo do encontro. In: Crítica Marxista $\mathrm{n}^{\circ} 20$. Rio de Janeiro: Editora Revan, 2005.

2.___. Machiavel et nous. In: Écrits philosophiques et politiques. Tome II. Paris: STOCK/ IMEC, 1995.

3.__Élément d'autocritique. Paris: Hachete Littérature, 1974.

4. . Le marxisme come théorie "finie" e Solitude de Machiavel (1977). In: Solitude de Machiavel et autres textes. Paris: PUF, 1998. / O marxismo como teoria "finita". In: Revista Outubro n². São Paulo: Instituto de Estudos Socialistas, 1998.

5.GRAMSCI, Antonio. Cadernos do Cárcere - Vol 3: Maquiavel. Notas sobre o Estado e Politica. Rio de Janeiro: Civilização Brasileira 2000.

6.MORFINO, Vittorio. La storia come "revoca permanente dell fato compiuto": Machiavelli nell'ultimo Althusser. In: Spinoza e Il non contemporaneo. Verona: ombre corte, 2009.

7.TOSEL, André. Les aléas du matérialisme aléatoire dans la dernière philosophie de Louis Althusser . Cahiers Philosophique, n⿳084 - Septembre, 2000.

\section{MACHIAVELLI OR THE LONGEST DETOUR: HAPPENING, MEETING AND MATERIALISM IN THE LAST ALTHUSSER'S PHILOSOPHY}

Abstract: This paper intends to outline a reading of a theory of the event in the "last Althusser" based in two texts of capital importance in the group of his phostumous works: Machiavel et nous (1972-1986) e Le courant souterrain du matérialisme de la rencontre (1982). In the first text, Althusser analyses the thought of the Florentine secretary reflecting about a theory of praxis of the political transformation, while in the second essay, he seeks to undertake the task to build a genealogical stream of materialism where the primacy of the encounter replaces the teleology of dialetic materialism. Based in these writings, we would like to seek a compositive read of these two essays in order to perceive if we can read on the althusserian ontology of the encounter and in the interpretation of Machiavelli's thought a theory of the event. Keywords: Althusser, Event, Encounter, Machiavelli, materialism

\section{NOTAS}

1. Dizemos aqui que o epicurismo está nos primórdios de uma reflexão materialista não apenas por uma questão referente a história da filosofia, mas nos referindo mais propriamente ao fato de que o epicurismo esteve no princípio das reflexões materialistas de Marx - questão muito bem conhecida por Althusser. Ver: MARX, Karl. Diferença entre as filosofias da natureza em Demócrito e Epicuro. Tr. Edson Bini e Armandina Venâncio. São Paulo: Global Editora, s.d.

2. Cf. ALTHUSSER 1, p.546 : "Poder-se-á dizer que, neste caso, se trata somente de filosofia política, sem enxergar que há ali, ao mesmo tempo, uma filosofia em funcionamento. Filosofia singular, que é um "materialismo do encontro" pensado através da política, e que, enquanto tal, não supõe nada preestabelecido." Ver também ALTHUSSER 2, p.81.

3. Com relação às citações textuais de Le courant souterrain, optamos aqui, por utilizar a tradução para o português de Mónica G. Zoppi Fontana presente na revista Crítica Marxista n$^{\circ} 20$-2005. Tal opção se deve não apenas a excelente qualidade da tradução, mas também, para divulgar a mesma - visto que não existe uma tradução brasileira do tomo I dos Écrits philosophiques et politiques. Para que o leitor possa consultar nossas referências textuais nesta tradução brasileira, colocaremos após a página do original em francês a página da tradução brasileira em negrito (Ex: ALTHUSSER 1, 
p 534/12). Tal tradução pode ser acessada através do seguinte endereço eletrônico: www.unicamp.br/cemarx/criticamarxista/critica20-A-althusser.pdf

4. Cf. MORFINO 6: "Althusser parece repetir a interpretação gramsciana de Maquiavel como teórico do Estado nacional. Esta repetição tem na verdade a função precisa de opor-se a filosofia da história, de romper o jogo de espelhos entre príncipe e partido fundado pela teleologia" (Minha tradução).

5. Utilizamos aqui a tradução de Márcio Bilharinho Naves para a Revista Outubro $n^{\circ}$ 20. Para que o leitor possa consultar nossas referências textuais nesta tradução brasileira, colocaremos após a página do original em francês a página da tradução brasileira em itálico ( Ex: ALTHUSSER 4, p. 285-286 / 65). A tradução em português pode ser acessada na internet pelo seguinte link: www.revistaoutubro.com.br/ edicoes/02/out2_05.pdf.

\section{DUAS LEITURAS DO CAPITALISMO EM MARX}

Renan Gonçalves Rocha**

Resumo: A compreensão piramidal do sistema capitalista em Marx, isto é, a concepção que estabelece a determinação da base econômica sobre a superestrutura (direito, Estado e ideologias) foi uma formulação bastante difundida pela teoria athusseriana. Não obstante, essa compreensão piramidal do capitalismo negligencia o papel determinante do aparato jurídico-político sobre os processos econômicos. Dessa forma, pretende-se mostrar que na relação entre economia e Estado em Marx há co-determinação, e não uma determinação unidirecional da economia sobre o Estado.

Palavras-chave: Althusser, Marx, Estado, economia, determinação, co-determinação.

Há uma análise do capitalismo atribuída a Marx, que estabelece que os processos socioeconômicos determinam de forma unidirecional o aparato jurídico-político. É uma compreensão piramidal do capitalismo, na qual a infraestrutura econômica determina a superestrutura jurídicopolítica e a ideológica. Tal analise do capitalismo foi atribuída a Marx tanto por teóricos marxistas (como Louis Althusser ${ }^{1}$ ), quanto por estudiosos não marxistas (como Norberto Bobbio ${ }^{2}$ ).

* Este texto foi apresentado com o título Uma reflexão crítica sobre o edifício social em Althusser. Por considerar que não é propriamente uma crítica ao pensamento de Althusser, mas uma releitura de Marx (partindo, de certa forma, de Althusser) decidimos mudar o título do texto.

**Renan Gonçalves Rocha (renangrocha@yahoo.com.br) é mestre em filosofia pela Universidade Federal de Goiás (UFG) e professor do Instituto Federal de Goiás (IFG). 